\title{
Restriction Fragment Length Polymorphism Studies Show Consistent Loss of Chromosome 3p Alleles in Small Cell Lung Cancer Patients' Tumors
}

\author{
Bruce E. Johnson, A. Y. Sakaguchi, * Adi F. Gazdar, John D. Minna, David Burch, Angus Marshall, a and Susan L. Naylor* \\ National Cancer Institute-Navy Medical Oncology Branch, National Cancer Institute and Naval Hospital and the Department \\ of Pathology, Naval Hospital, Bethesda, Maryland 20814; and *The Department of Cellular and Structural Biology, \\ The University of Texas Health Sciences Center at San Antonio, San Antonio, Texas 78284
}

\begin{abstract}
Previous karyotypic analysis of human small cell lung cancer cell lines has demonstrated a consistent deletion of a portion of the short arm of chromosome 3(p14-23). DNA prepared from tumors and normal tissues obtained from 24 small cell lung cancer and two extrapulmonary small cell cancer patients was hybridized to four probes that detect restriction fragment length polymorphisms within chromosome region 3p14-21. Of the 25 patients who were heterozygous for at least one marker in this region in the DNA from normal tissue, $23(92 \%)$ showed an unequivocal loss of heterozygosity in the DNA from their tumor tissue. From these studies we conclude that loss of alleles from the short arm of chromosome 3 is a consistent finding in unselected small cell lung cancer patients' tumor DNA.
\end{abstract}

\section{Introduction}

The deletion of chromosomal regions in specific cancers was initially identified by karyotype analysis of childhood tumors. Karyotype studies and biochemical analysis of esterase D in familial retinoblastoma tumors and normal tissues identified chromosome $13 \mathrm{q} 14$ as the critical region for deletion in this cancer (1-5). Subsequent DNA restriction fragment length polymorphism studies using probes that map at or near $13 q 14$ in nonfamilial cases demonstrated deletion of genetic material in sporadic cases as well $(6,7)$. In a subset of Wilms' tumor patients with accompanying aniridia, a deletion of chromosome $11 \mathrm{p} 13$ was identified cytogenetically $(8,9)$. Additional studies using $11 \mathrm{p}$ restriction fragment length polymorphism probes in sporadic Wilms' tumor patients whose tumors appear karyotypically normal have also demonstrated deletion of genetic material in the area of $11 \mathrm{p} 13$ in tumor compared to their normal tissue DNA (10-12). Therefore, in both of these rare childhood tumors, karyotypic analysis of familial or congenital cases has identified regions of chromosomes that have also been shown to be deleted in sporadic cases by restriction fragment length polymorphism studies of normal and tumor tissue DNA.

In contrast to these rare childhood tumors, small cell lung cancer is a common adult tumor with more than 30,000 cases per year in the United States (13). Small cell lung cancer is one

Address reprint requests to Dr. Naylor, Department of Cellular and Structural Biology, University of Texas Health Sciences Center, San Antonio, TX 78284 .

Received for publication 11 August 1987 and in revised form 28 December 1987.

The Journal of Clinical Investigation, Inc.

Volume 82, August 1988, 502-507 of the few adult solid tumors where a consistent chromosomal abnormality has been described. A deletion involving chromosome bands 3p14-23 has been identified by shortest overlap analysis of cytogenetic data from small cell lung cancer cell lines and tumors (14-17). Most of this cytogenetic analysis was performed on small cell lung cancer cell lines. Tumor cell lines are established from a minority of our small cell lung cancer patients and these patients have a shortened survival compared with patients who do not have cell lines established (18). Therefore, the tumor cell lines may not be typical of all small cell lung cancer patients' tumors but may be more likely to be established from patients with aggressive tumors leading to a shortened patient survival. In addition, cell culture conditions may select for a nonrepresentative subpopulation of tumor cells. Therefore we considered it important to study chromosome $3 p$ in tumors taken directly from patients before cell culture conditions.

While cytogenetic studies targeted the $3 p$ region, the aneuploidy of the tumor cells and multiple other chromosomal changes left open the possibility that the $3 p$ region was relocated in the tumor cell genome and was not actually deleted. We have recently shown using DNA probes that detect restriction fragment length polymorphisms within 3 p14-23 that the DNA markers localized to the short arm of chromosome 3 lose their heterozygosity in DNA prepared from seven small cell lung cancer patients' tumors and two cell lines (19) suggesting actual loss of DNA from the $3 p$ region. However, this small sample size precluded extrapolating this data to the full range of small cell lung cancer patients. In this report, we extend our analysis by 19 additional patients representing a more diverse spectrum of the disease. In addition, established tumor cell lines are available for study from some of these small cell cancer patients (20). This now allows us to investigate this deletion in a series of 26 tumor samples obtained directly from 24 unselected small cell lung cancer patients and 2 extrapulmonary small cell cancer patients in a variety of clinical situations. In the present study four probes that detect restriction fragment length polymorphisms within the previously described deletion of chromosome 3p14-23 were used to investigate allele loss from DNA prepared from tumors obtained directly from patients before cell culture conditions.

\section{Methods}

Tumors and normal tissues were obtained from 24 patients with histologically documented small cell lung cancer and 2 with extrapulmonary small cell cancer treated on institutional review board approved protocols at the NCI-Navy Medical Oncology Branch. The patients' clinical characteristics and course were reviewed and the age, sex, stage of disease, history of chemotherapy treatment, response to chemotherapy, and survival were recorded. The patients were staged as limited, extensive stage disease or extrapulmonary and the response to chemo- 
therapy was defined as partial or complete as previously described (21). Survival was measured from the initiation of chemotherapy treatment.

Tumor and normal tissues procured at postmortem examinations were grossly identified, collected, and reviewed by the authors, including an anatomic pathologist. Normal tissue was obtained by serially sectioning an uninvolved organ with subsequent histological documentation of lack of tumor involvement. Tumor cell lines were established using techniques previously described (20).

High molecular weight DNA was prepared from tumors and normal tissue using finely minced tissue by the method of Hieter (22) while DNA was prepared from cell lines as previously described (18). 5 $\mu \mathrm{g}$ of DNA was digested with appropriate restriction endonucleases, electrophoresed in $0.8 \%$ agarose, transferred to nylon filters and hybridized to radiolabeled DNA fragments. The eight chromosome 3 probes used in this study are listed in Table I.

\section{Results}

Tumor and normal tissue was available for study from 26 small cell cancer patients treated at the NCI-Navy Medical Oncology Branch from 1983 to 1986 (Table II). The restriction fragment length polymorphism data on patients 1-7 has been previously reported and the same numbering system is used in this report (19). This series of small cell cancer patients had a median age of 56 (range 35-75). There were 18 males and 8 females; 9 limited stage, 15 extensive stage patients, and 2 patients with extrapulmonary small cell cancer. Patient 8 presented with extrapulmonary small cell cancer in his prostate with multiple metastatic sites and his postmortem examination showed no evidence of a primary lung tumor. Patient number 18 had extrapulmonary small cell cancer in his cervical lymph node with a normal chest radiograph and fiberoptic bronchoscopic examination. Tumor tissue from 20 patients was obtained after combination chemotherapy treatment while six were obtained before treatment. Of the 21 patients evaluable for response, 13 patients had a complete response, 6 had a partial response, and 2 had no response. The median survival of these 26 patients was $12 \mathrm{mo}$, range 0-67 mo.

25 of the 26 patients had heterozygous loci detected in the DNA prepared from their normal tissue with at least one of the four probes (pMS1-37, p12-32, pH3H2, and pH3E4) identifying restriction fragment length polymorphisms in the region of 3p14-21 (Table III). 22 of these 25 tumor DNAs (88\%) showed reduction to homozygosity of one or more heterozygous loci detected in normal tissue DNA within 3p14-21 (Table I). Fig. 1 depicts examples of loss of heterozygous alleles in the DNA from two small cell lung cancer patients' tumor tissue com-

Table I. Chromosome 3 Probes Detecting Restriction Fragment Length Polymorphisms

\begin{tabular}{lllll}
\hline Probes & $\begin{array}{c}\text { Restriction } \\
\text { endonuclease }\end{array}$ & Locus & $\begin{array}{c}\text { Chromosomal } \\
\text { localization }\end{array}$ & References \\
\hline $\begin{array}{c}\text { 3p Probes } \\
\text { pMS1-37 }\end{array}$ & Msp I & D3S3 & $3 p 14.2$ & $(23-25)$ \\
p12-32 & Msp I & D3S2 & $3 p(14.2-21)$ & $(24,26,27)$ \\
pH3H2 & Hind III & DNF15S2 & $3 p 21$ & $(28-31)$ \\
pH3E4 & Hind III & DNF15S2 & $3 p 21$ & $(29-31)$ \\
3q Probes & & & & \\
HS-3 & Hind III & D3S1 & $3 q 12$ & $(32)$ \\
TF & Eco RI & & $3 q 21$ & $(33)$ \\
CP & Pst I & & $3 q 25$ & $(34)$ \\
SST & Bam HI and & & $3 q 28$ & $(35)$ \\
& Eco Ri & & & \\
\hline
\end{tabular}

Table II. Clinical Characteristics of Small Cell Lung Cancer Patients Whose Tumor and Normal DNA Was Analyzed for Allele Loss of $3 p$ Using Restriction Fragment Length Polymorphisms

\begin{tabular}{|c|c|c|c|c|c|c|}
\hline $\begin{array}{l}\text { Patient } \\
\text { No. }\end{array}$ & Age & Sex & Stage & $\begin{array}{l}\text { Chemotherapy } \\
\text { treatment }\end{array}$ & Response & Survival \\
\hline & $y r$ & & & & & mo \\
\hline 1 & 49 & $\mathrm{~F}$ & Ext & No & - & 0 \\
\hline 2 & 56 & $\mathrm{~F}$ & Ext & Yes & CR & 13 \\
\hline 3 & 46 & $\mathbf{M}$ & Ltd & Yes & CR & 15 \\
\hline 4 & 54 & $\mathbf{M}$ & Ext & Yes & CR & 22 \\
\hline 5 & 60 & $\mathbf{M}$ & Ltd & Yes & CR & 11 \\
\hline 6 & 47 & $\mathbf{M}$ & Ext & Yes & PR & 9 \\
\hline 7 & 56 & $\mathbf{M}$ & Ext & No & - & 0 \\
\hline 8 & 63 & $\mathbf{M}$ & Extra* & No & - & 0 \\
\hline 9 & 63 & $\mathbf{M}$ & Ext & Yes & CR & 12 \\
\hline 10 & 61 & $\mathbf{M}$ & Ext & Yes & CR & 14 \\
\hline 11 & 55 & $\mathbf{M}$ & Ext & Yes & NR & 4 \\
\hline 12 & 52 & $\mathrm{~F}$ & Ltd & Yes & CR & 19 \\
\hline 13 & 43 & $\mathbf{M}$ & Ext & Yes & PR & 6 \\
\hline 14 & 63 & $\mathbf{M}$ & Ltd & Yes & NR & 3 \\
\hline 15 & 64 & $\mathbf{F}$ & Ext & Yes & PR & 13 \\
\hline 16 & 73 & $\mathrm{~F}$ & Ext & No & - & 0 \\
\hline 17 & 64 & $\mathbf{M}$ & Ext & Yes & PR & 11 \\
\hline 18 & 62 & $\mathbf{M}$ & Extra* & No & PR & 10 \\
\hline 19 & 48 & $\mathbf{M}$ & Ltd & Yes & CR & 15 \\
\hline 20 & 54 & $\mathbf{M}$ & Ltd & Yes & CR & 28 \\
\hline 21 & 35 & $\mathbf{F}$ & Ext & Yes & CR & 67 \\
\hline 22 & 67 & $\mathbf{M}$ & Ltd & Yes & CR & 21 \\
\hline 23 & 75 & $\mathbf{M}$ & Ext & No & - & 0.5 \\
\hline 24 & 63 & $\mathbf{M}$ & Ext & Yes & CR & 23 \\
\hline 25 & 60 & $\mathrm{~F}$ & Ltd & Yes & CR & 9 \\
\hline 26 & 51 & $\mathrm{~F}$ & Ltd & Yes & PR & 13 \\
\hline
\end{tabular}

* Extra denotes extrapulmonary small cell lung cancer; Ext, extensive stage disease; Ltd, limited state disease; CR, complete response; PR, partial response; and NR, no response.

pared with their normal tissue DNA. The normal tissue DNA prepared from patients 5 and 6 had two alleles $(2.9$ and $1.3 \mathrm{~kb}$ ) when digested with the restriction endonuclease MspI and hybridized to the probe p12-32 (D3S2). The small cell lung cancer tissue DNA prepared from patients 5 and 6 had only one allele $(2.9 \mathrm{~kb})$ when digested with Msp I and hybridized to p12-32. Therefore, the allele corresponding to $1.3 \mathrm{~kb}$ has been lost in the DNA from tumor tissue compared to the DNA from normal tissue from the same patient. Patient number 10 was the only patient that had multiple heterozygous loci detected in his normal DNA and only one of the three loci is reduced to homozygosity in his tumor DNA. In patient 10 , the heterozygous locus detected by $\mathrm{pH} 3 \mathrm{H} 2$ at $3 \mathrm{p} 21$ in normal tissue DNA is reduced to homozygosity in the tumor DNA while the heterozygous loci detected more proximally at 3p14 (D3S3) and 3p14-21 (D3S2) are retained in the tumor DNA (Table III). The other 21 patients' tumor DNA showed reduction to homozygosity of all heterozygous loci detected in normal tissue DNA by probes that detect restriction fragment length polymorphisms and have been mapped to 3p14-23 (Table I).

DNA from the tumor sample of patient 14 collected at autopsy showed persistence of the heterozygous locus (DNF15S2) present in DNA prepared from his normal tissue. 
Table III. Comparison of Chromosome 3 Alleles in Tumor and Normal Tissue DNA from Small Cell Lung Cancer Patients

\begin{tabular}{|c|c|c|c|c|c|c|c|c|c|}
\hline $\begin{array}{c}\text { Probes. . . } \\
\text { Locus. . }\end{array}$ & $\begin{array}{c}\text { pH3H2 } \\
\text { DNF15S2 }\end{array}$ & $\begin{array}{c}\text { pH3E4 } \\
\text { DNF15S2 }\end{array}$ & $\begin{array}{c}\text { p12-32 } \\
\text { D3S2 }\end{array}$ & $\begin{array}{c}\text { pMS1-37 } \\
\text { D3S3 }\end{array}$ & $\begin{array}{c}\text { Probes. . . } \\
\text { Locus. . }\end{array}$ & $\begin{array}{c}\text { pH3H2 } \\
\text { DNF15S2 }\end{array}$ & $\begin{array}{c}\text { pH3E4 } \\
\text { DNF15S2 }\end{array}$ & $\begin{array}{l}\text { p12-32 } \\
\text { D3S2 }\end{array}$ & $\begin{array}{c}\text { pMS1-37 } \\
\text { D3S3 }\end{array}$ \\
\hline & & & & & $\mathrm{N}-14$ & 1,2 & & NT & \\
\hline $\mathrm{N}-1$ & 1,2 & & & & SCLC-14 & 1,2 & & & \\
\hline SCLC-1 & 2 & & & & H847 & 1 & & & \\
\hline $\mathrm{N}-2$ & & & 1,2 & & $\mathrm{~N}-15$ & 1,2 & & NT & \\
\hline SCLC-2 & & & 2 & & SCLC-15 & 1 & & & \\
\hline $\mathrm{N}-3$ & 1,2 & & & 1,2 & $\mathrm{~N}-16$ & 1,2 & & & \\
\hline SCLC-3 & 2 & & & 1 & SCLC-16 & 1 & & & \\
\hline N-4 & 1,2 & & 1,2 & 1,2 & $\mathrm{~N}-17$ & & & & \\
\hline SCLC-4 & 1 & & 2 & 1 & SCLC-17 & & & & \\
\hline N-5 & 1,2 & & 1,2 & 1,2 & $\mathrm{~N}-18$ & & & 1,2 & \\
\hline SCLC-5 & 2 & & 1 & 1 & SCLC-18 & & & 1 & \\
\hline N-6 & & & 1,2 & 1,2 & $\mathrm{~N}-19$ & 1,2 & & & \\
\hline SCLC-6 & & & 1 & 2 & SCLC-19 & 1,2 & & & \\
\hline $\mathrm{N}-7$ & & & 1,2 & & $\mathrm{~N}-20$ & 1,2 & & & \\
\hline SCLC-7 & & & 2 & & SCLC-20 & 2 & & & \\
\hline $\mathrm{N}-8$ & 1,2 & & 1,2 & & $\mathrm{~N}-21$ & 1,2 & 1,2 & & \\
\hline SCLC-8 & 1,2 & & 1,2 & & SCLC-21 & 2 & 1 & & \\
\hline H660 & 1,2 & & 1,2 & & $\mathrm{~N}-22$ & 1,2 & & 1,2 & \\
\hline N-9 & & & 1,2 & & SCLC-22 & 2 & & 2 & \\
\hline SCLC-9 & & & 2 & & $\mathrm{~N}-23$ & 1,2 & & & \\
\hline $\mathrm{N}-10$ & 1,2 & & 1,2 & 1,2 & SCLC-23 & 2 & & & \\
\hline SCLC-10 & 2 & & 1,2 & 1,2 & $\mathrm{~N}-24$ & 1,2 & 1,2 & & \\
\hline $\mathrm{N}-11$ & & & 1,2 & 1,2 & SCLC-24 & 1 & 1 & & \\
\hline SCLC-11 & & & 2 & 1 & $\mathrm{~N}-25$ & & & 1,2 & \\
\hline $\mathrm{N}-12$ & 1,2 & & & 1,2 & SCLC-25 & & & 2 & \\
\hline SCLC-12 & 1 & & & 2 & $\mathrm{~N}-26$ & 1,2 & & & NT \\
\hline $\mathrm{N}-13$ & 1,2 & & & & SCLC-26 & 2 & & & NT \\
\hline SCLC-13 & 1 & & & & & & & & \\
\hline
\end{tabular}

$\mathrm{N}$ denotes normal tissue and SCLC denotes small cell lung cancer tumor tissue. 1, 2 denotes a heterozygous allele and a single number (1 or 2) represent reduction to homozygosity. NT denotes not tested and a blank space means that the allele was noninformative (not heterozygous).

His small cell lung cancer had been treated with chemotherapy for 3 mo before his death from infectious complications. The histologic review of his autopsy tissue showed necrotic cells

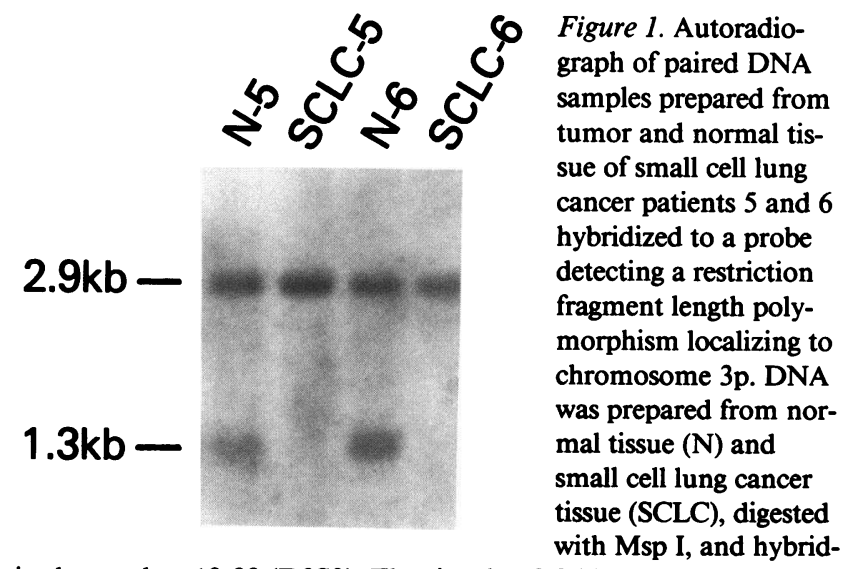

ized to probe p12-32 (D3S2). The signal at $2.9 \mathrm{~kb}$ represents allele 1 and the signal at 1.3 kilobases in the normal tissue represents allele 2. with little evidence of cancer. Therefore, the persistence of the heterozygous locus (DNF15S2) in the DNA from the autopsy tissue specimen we initially believed to contain tumor by gross examination was probably from the predominance of DNA prepared from the normal cells in the autopsy tissue specimen. We were able to establish a tumor cell line from patient number 14 before his death. The DNA from this small cell lung cancer cell line, H847, showed a loss of heterozygosity compared to the DNA from his normal tissue (Table III).

The clinical situation of patient 8 was consistent with a diagnosis of extrapulmonary small cell cancer. He presented with a prostate primary tumor and a subsequent autopsy showed no evidence of a primary tumor in his lung. The tumor DNA showed persistence of heterozygosity of the restriction fragment length polymorphisms detected by probes $\mathrm{pH} 3 \mathrm{H} 2$ and p12-32 in the normal DNA. The cell line, H660, established from patient 8 also showed persistence of heterozygosity at both loci (DNF15S2 and D3S2) in the tumor cell line DNA. The morphologic and biochemical analysis of the cell line were consistent with a small cell cancer tumor cell line (20). The DNA from the tumor tissue of patient 19 showed persistence 
of heterozygosity of the single restriction fragment length polymorphism (DNF15S2) present in his normal tissue.

The tumor DNA from 24 patients was also studied for loss of heterozygosity of restriction fragment length polymorphisms detected by recombinant DNA probes that detect loci mapping to the long arm of chromosome 3 (HS-3, transferrin [TF], ceruloplasmin [CP], and somatostatin [SST]) compared to normal tissue DNA (Table I). DNA isolated from the normal tissue of 19 patients had heterozygous loci on the long arm of chromosome 3.4 of these 19 showed loss of heterozygosity in the DNA from tumor tissue compared to DNA from normal tissue. The tumor DNA from patients 4 and 19 showed reduction to homozygosity of the only heterozygous locus detected in normal tissue DNA (HS-3). The tumor DNA from patient 15 showed a loss of heterozygosity of one (HS-3) of the two heterozygous loci (HS-3 and CP) detected in normal DNA. The tumor DNA from patient 16 showed a loss of heterozygosity of one (CP) of the three heterozygous loci (TF, CP, and SST) detected in the normal DNA. None of the four nonsmall cell lung cancers, one pancreatic cancer, and one colon cancer studied showed loss of heterozygous $3 \mathrm{p}$ alleles in tumor DNA compared with normal tissue DNA.

To investigate loss of DNA alleles from other chromosomes, recombinant DNA fragments that detect restriction fragment length polymorphism on chromosomes other than three were hybridized to normal and tumor DNA. The normal DNA from the 26 small cell cancer patients was studied with DNA fragments (pIE8 and p9A7) that detect restriction fragment length polymorphisms on the long arm of chromosome 13 between 13q22 to 13qter (36) when the DNA is digested with Msp I (pIE8 and p9A7) or Hind III (p9A7). The normal DNA from 12 patients was heterozygous for one or more of these alleles. The tumor DNA from 8 of these 12 showed reduction to homozygosity compared to the normal DNA. DNA fragments that detect restriction fragment length polymorphisms on chromosomes 5, 8, 9, 10, 20, 21, and 22 were hybridized to tumor and normal DNA from patients $1-7$. Heterozygous loci were detected in the DNA from normal tissue in 1-7 (median 3) of the patients for each of the DNA fragments. The probes showed a reduction to homozygosity in the tumor DNA from one of the four patients with heterozygous loci in their normal DNA on chromosome 5, one of five with heterozygous loci on chromosome 14 , one of three with heterozygous loci on chromosome 15 , and two of seven with heterozygous loci on chromosome 20.

\section{Discussion}

The previous karyotypic description of loss of one homolog of the short arm of chromosome 3 with the smallest overlap region of 3p14-23 in small cell lung cancer cell lines and tumors (14-17) has not been observed by all investigators (37). This study, using probes that identify restriction fragment length polymorphisms in normal tissue DNA in the area previously described as being deleted in small cell lung cancer cell lines, has provided additional evidence for consistent loss of heterozygosity in the tumor DNA compared to the normal tissue DNA from the same small cell lung cancer patient. In addition, the tumor DNA from patient 10 shows reduction to homozygosity of a heterozygous locus (DNF15S2) detected at 3 p21 in normal tissue DNA while retaining heterozygous loci

1. Abbreviations used in this paper: $\mathrm{CP}$, ceruloplasmin; SST, somatostatin; TF, transferrin. in his tumor DNA at 3p14 (D3S3) and 3p14-21 (D3S2). This potentially localizes the important deleted segment of DNA as distal to the D3S2 locus and suggests that DNF15S2 may be more closely linked with the important deleted segment of DNA.

This study of 26 unselected small cell cancer patients shows that reduction to homozygosity in tumor DNA of heterozygous loci in normal DNA from the short arm of chromosome 3 is not confined to a subset of patients but is a consistent finding in small cell lung cancer. This loss of alleles is consistent in tumors from small cell lung cancer patients regardless of age, sex, stage, chemotherapy treatment status, or survival (Table II). In addition, studying a defined cohort of patients with clinical information available has allowed us to document that these 24 small cell lung cancer patients have similar characteristics and clinical courses as other typical series of small cell lung cancer patients (38).

Small cell lung cancer cell lines have previously been shown to be established from patients with a more aggressive shortened clinical course (18). In addition, cell culture conditions may select a subpopulation of cells present in a tumor and it is currently unknown to what extent a cell line is representative of a particular tumor. This study has shown that the loss of alleles from chromosome $3 p$ takes place in tumors from patients in all clinical settings and not just in those patients whose tumor has grown in cell culture.

The availability of clinical histories, tumor cell line DNA, plus histologic review of tumor and normal tissue specimens has allowed us to propose potential explanations for the observations made in patients 14 and 8 . The review of histologic sections from what was believed to be a tumor specimen at postmortem examination from patient 14 showed a predominance of normal cells with very few viable tumor cells present. The study of DNA from the tumor cell line established from patient number 14, H847, showed reduction to homozygosity of a heterozygous locus (DNF15S2) present in normal DNA. Therefore we believe that the persistence of heterozygosity present in what was judged to be tumor tissue actually represents the contaminating normal cells, and the loss of heterozygosity of the $3 p$ loci in the tumor cell line DNA represent the patient's cancer.

There are two exceptions to the consistent loss of heterozygosity of $3 p$ loci in tumor DNA from small cell cancer patients. In patient 8 neither the tumor nor the tumor cell line (H660) DNA from patient 8 showed loss of heterozygosity of $3 p$ loci compared to normal tissue DNA (using currently available probes). Despite the biochemical and morphological characteristics typical of small cell cancer in the cell line established from this patient (20), he has a very unusual presentation. Although this patient had a histologic diagnosis of small cell cancer, his cancer started in his prostate gland with no evidence of primary cancer in his lung and may be biologically different explaining the persistence of heterozygosity in his tumor DNA for both chromosome $3 p$ heterozygous loci detected in his normal DNA. The presence of a heterozygous locus in tumor DNA from patient 19 could represent the absence of deletion of DNA from $3 p$ or the deletion did not encompass the heterozygous locus at $3 \mathrm{p} 21(\mathrm{pH} 3 \mathrm{H} 2)$ detected in normal DNA. Alternatively, the probes used in this study may not detect rare small deletions in small cell lung cancer tumors.

The reduction to homozygosity of heterozygous loci mapping to areas of chromosome 3 other than the short arm is not 
a common event in small cell lung cancer tumor DNA. 4 of 19 small cell cancer tumor DNAs showed a reduction to homozygosity of one heterozygous locus mapping to $3 q$ compared to normal tissue DNA and two of these four still had other heterozygous loci mapping to $3 \mathrm{q}$ present in their tumor DNA. Therefore the loss of chromosome 3 alleles in small cell lung cancer appears to typically involve the short arm of chromosome 3 because heterozygous loci on the long arm of chromosome 3 are retained in 17 of $19(89 \%)$ small cell lung cancer patients' tumor DNA. This is consistent with the previous cytogenetic $(14,15)$ and restriction fragment length polymorphism studies (19) suggesting the most common mechanism of loss of genetic information from chromosome $3 p$ is an intersititial or terminal deletion.

The long arm of chromosome 13 was the only other chromosomal area studied where the loss of heterozygosity of restriction fragment length polymorphisms commonly occurs in tumor DNA. Of the 12 patients who had heterozygous loci detected by DNA fragments that map to $13 q 22$ to $13 q$ ter, 8 showed reduction to homozygosity. This is of interest because this same locus has been reported to be deleted in retinoblastoma tumor DNA by restriction fragment length polymorphism studies and is near the Rb locus at 13q14 (1-7). Additional studies are needed to confirm this initial observation and to study the $\mathrm{Rb}$ locus more directly in small cell lung cancer. None of the DNA from six other adult carcinomas studied showed deletion of any $3 p$ alleles.

In tumors other than small cell lung cancer where deletions of genetic material may be important in the generation of malignancy, the identification of specific chromosomal deletions in retinoblastoma and Wilms' tumors was initially prompted by the cytogenetic analysis of normal lymphocytes and tumors in familial cases and congenital syndromes respectively $(1-5,8,9)$. The identification of families or congenital syndromes associated with small cell lung cancer is very rare (13). In contrast to retinoblastoma and Wilms' tumors where inheritance appears to play a significant role in the development of the tumor (39), nearly all small cell lung cancers are associated with cigarette smoking (13). The chromosomal deletion in small cell lung cancer, therefore, was initially identified in karyotypic analysis of sporadic cases of small cell lung cancer cell lines (14-17).

The identification of DNA deletions in familial and sporadic cases of retinoblastoma and Wilms' tumor DNA provides evidence for recessive genes playing a potential role in the pathogenesis of these tumors. The evidence for the existence of such recessive genes has been suggested by somatic cell hybrid studies between malignant and normal cells where malignancy was suppressed (40) and the occurrence of multiple retinoblastomas in familial cases (39). Additional evidence for recessive genes playing a potential role in the development of human malignancy was provided by a normal chromosome 11 suppressing tumor formation in athymic nude mice of a Wilms' tumor cell line with a $11 \mathrm{p}$ deletion (41).

The identification of a consistent loss of heterozygosity at $3 p$ loci in small cell lung cancer tumors using restriction fragment polymorphism studies provides additional support for this chromosomal region to be important in the generation of small cell lung cancer. It is of interest that the chromosome $3 p$ region is implicated in renal cell carcinoma as well. Zbar et al. described the loss of $3 p$ alleles in sporadic renal cell carcinoma using restriction fragment length polymorphism studies (42). Similar to the findings in our small cell lung cancer patients' tumor DNA, all heterozygous alleles in normal DNA detected at the DNF15S2 locus were reduced to homozygosity in the renal cell carcinoma DNA. In addition, Dr. Zbar identified a single patient where the heterozygous alleles detected in DNA from normal tissue at DNF15S2 were reduced to homozygosity in the tumor DNA, while the heterozygous alleles detected at D3S2 were retained in the tumor DNA similar to patient 10 presented here. If the same recessive gene located on $3 p$ is involved in the etiology of small cell lung cancer and renal cell carcinoma as has been proposed by Zbar (42), the gene appears to be more closely linked with DNF15S2 on $3 \mathrm{p} 21$ than with D3S2 or D3S3 on 3p14.

Abnormalities of chromosome 3 have also been identified in familial renal cell carcinoma. A $t(3 ; 8)$ (p14.2; q24.1) constitutional reciprocal translocation $(27,43)$ and a $3 ; 11$ translocation limited to the tumor cells (44) have been described in familial studies of renal cell carcinoma. The D3S2 probe hybridizes to the der $(8)$ chromosome in the familial $t(3 ; 8)$ constitutional reciprocal translocation (27), suggesting the breakpoint is proximal to the D3S2 locus. In contrast to these familial studies suggesting the important region on chromosome 3 is proximal to D3S2, the studies of small cell lung cancer DNA and sporadic renal cell carcinoma DNA would suggest that DNF15S2 is more closely linked to a potential recessive cancer gene, which is more distal on chromosome $3 p$ than D3S2. Potential reasons for the different chromosome 3 regions involvement in the familial cases of the $3 ; 8$ translocation in renal cell carcinoma versus small cell lung cancer and sporadic renal cell carcinoma include a different gene on chromosome 3 causing the familial renal cell carcinoma than small cell lung cancer and sporadic renal cell carcinoma, a submicroscopic deletion accompanies the chromosomal translocation in the $t(3 ; 8)$ familial renal cell carcinoma, or the constitutional translocation of chromosome 3 is not the etiologic event in the generation of the familial renal cell carcinoma but allows a deletion of DNA distal to the breakpoint on chromosome $3 p$ to subsequently occur. Cloning of cDNAs in this region will provide reagents to experimentally test this relationship. Additionally, further investigation is needed to determine if deletion of chromosome $3 p$ may be helpful in the clinical diagnosis of small cell lung cancer.

\section{Acknowledgments}

Supported in part by NIH CA-44764, Mather Foundation Z004, and Council for Tobacco Research Center 1620.

\section{References}

1. Strong, L. C., V. M. Riccardi, R. E. Ferrell, and R. S. Sparkes. 1981. Familial retinoblastoma and chromosome 13 deletion transmitted via an insertional translocation. Science (Wash. DC). 213:15011503.

2. Sparkes, R. S., A. L. Murphree, R. W. Lingua, M. C. Sparkes, L. L. Field, S. J. Funderburk, and W. F. Benedict. 1983. Gene for hereditary retinoblastoma assigned to human chromosome 13 by linkage to esterase D. Science (Wash. DC). 219:971-973.

3. Benedict, W. F., A. L. Murphree, A. Banerjee, C. A. Spina, M. C. Sparkes, and R. S. Sparkes. 1983. Patient with 13 chromosome deletion: evidence that the retinoblastoma gene is a recessive cancer gene. Science (Wash. DC). 219:973-975.

4. Sparkes, R. S., M. C. Sparkes, M. G. Wilson, J. W. Towner, W. Benedict, A. L. Murphree, and J. J. Yunis. 1980. Regional assignment of genes for human esterase D and retinoblastoma to chromosome band 13q14. Science (Wash. DC). 208:1042-1044. 
5. Yunis, J. J., and N. Ramsey. 1978. Retinoblastoma and subband deletion of chromosome 13. Am. J. Dis. Child. 132:161-163.

6. Cavenee, W. K., T. P. Dryja, R. A. Phillips, W. F. Benedict, R. Godbout, B. L. Gallie, A. L. Murphree, L. C. Strong, and R. L. White. 1983. Expression of recessive alleles by chromosomal mechanisms in retinoblastoma. Nature (Lond.). 305:779-784.

7. Dryja T. P., W. Cavenee, R. White, J. M. Rapaport, R. Petersen, D. M. Albert, and G. A. P. Bruns. 1984. Homozygosity of chromosome 13 in retinoblastoma. N. Engl. J. Med. 310:550-553.

8. Riccardi, V. M., E. Sujansky, A. C. Smith, and U. Francke. 1978. Chromosomal imbalance in the Aniridia-Wilms' tumor association: $11 \mathrm{p}$ interstitial deletion. Pediatrics. 61:604-609.

9. Miller, R. W., J. F. Fraumeni, and M. D. Manning. 1964. Association of Wilms' tumor with aniridia, hemihypertrophy and other congenital malformations. $N$. Engl. J. Med. 270:922-927.

10. Orkin, S. H., D. S. Goldman, and S. E. Sallan. 1984. Development of homozygosity for chromosome $11 \mathrm{p}$ markers in Wilms' tumour. Nature (Lond.). 309:172-174.

11. Reeve, A. E., P. J. Housiaux, R. J. M. Gardner, W. E. Chewings, R. M. Grindley, and L. J. Millow. 1984. Loss of a Harvey ras allele in sporadic Wilms' tumour. Nature (Lond.). 309:174-176.

12. Fearon, E. R., B. Vogelstein, and A. P. Feinberg. 1984. Somatic deletion and duplication of genes on chromosome 11 in Wilms' tumours. Nature (Lond.). 309:176-178.

13. Minna, J. D., G. A. Higgins, and E. J. Glatstein. 1985. Cancer of the Lung. In Cancer: Principles and Practice of Oncology. V. T. DeVita, S. Hellman, and S. A. Rosenberg, editors. J. B. Lippincott Co., Philadelphia. 507-597.

14. Whang-Peng, J., P. A. Bunn, Jr., C. S. Kao-Shan, E. C. Lee, D. N. Carney, A. Gazdar, and J. D. Minna. 1982. A nonrandom chromosomal abnormality, del $3 p(14-23)$, in human small cell lung cancer (SCLC). Cancer Genet. Cytogenet. 6:119-134.

15. Whang-Peng, J., C. S. Kao-Shan, E. C. Lee, P. A. Bunn, D. N. Carney, A. F. Gazdar, and J. D. Minna. 1981. Specific chromosome defect associated with human small-cell lung cancer: Deletion $3 \mathrm{p}(14-$ 23). Science (Wash. DC). 215:181-182.

16. Falor, W. H., R. Ward-Skinner, and S. Wegryn. 1985. A 3p deletion in small cell lung carcinoma. Cancer Genet. Cytogenet. 16:175-177.

17. Yunis, J. J. 1983. The chromosomal basis of human neoplasia. Science (Wash. DC). 221:227-236.

18. Johnson, B. E., D. C. Ihde, R. W. Makuch, A. F. Gazdar, D. N. Carney, H. Oie, E. Russell, M. M. Nau, and J. D. Minna. 1987. myc family oncogene amplification in tumor cell lines established from small cell lung cancer patients and its relationship to clinical status and course. J. Clin. Invest. 79:1629-1634.

19. Naylor, S. L., B. E. Johnson, J. D. Minna, and A. Y. Sakaguchi. 1987. Loss of heterozygosity of chromosome 3p markers in small cell lung cancer. Nature (Lond.). 329:451-454

20. Carney, D. N., A. F. Gazdar, G. Bepler, J. G. Guccion, P. J. Marangos, T. W. Moody, M. H. Zweig, and J. D. Minna. 1985. Establishment and identification of small cell lung cancer cell lines having classic and variant feature. Cancer Res. 45:2913-2923.

21. Bunn, P. A., Jr., A. S. Lichter, R. W. Makuch, M. H. Cohen, S. R. Veach, M. J. Matthews, A. Johnston Anderson, M. Edison, E. Glatstein, and J. D. Minna. 1987. Chemotherapy alone or chemotherapy with chest radiation therapy in limited stage small cell lung cancer. Ann. Intern. Med. 106:655-662.

22. Heiter, P. A., G. F. Hollis, S. J. Korsmeyer, T. A. Waldman, and P. Leder. 1981. Clustered arrangement of immunoglobulin lambda constant region genes in man. Nature (Lond.). 294:536-540.

23. de Martinville, B., M. Shafer, R. White, and U. Francke. 1984. Assignment of RFLP loci D3S3, D2054, and D15S1 to chromosomes 3p, 20, and 15, respectively. Cytogenet. Cell Genet. 37:531-532.

24. Barker, D., M. Schafer, and R. White. 1984. Restriction sites containing $\mathrm{CpG}$ show a higher frequency of polymorphism in human DNA. Cell. 36:131-138.

25. Gerber, M. J., Y. E. Miller, H. A. Drabkin, and C. H. Scoggins.
1986. Regional assignment of the polymorphic probe D3S3 to $3 p 14$ by molecular hybridization. Cytogenet. Cell Genet. 42:72-74.

26. Naylor, S. L., A. Y. Sakaguchi, D. Barker, R. White, and T. B. Shows. 1984. DNA polymorphic loci mapped to human chromosomes 3, 5, 9, 11, 17, 18, and 22. Proc. Natl. Acad. Sci. USA. 81:2447-2451.

27. Harris, P., C. C. Morton, P. Guglielmi, F. Li, K. Kelly, and S. A. Latt. 1986. Mapping by chromosome sorting of several gene probes, including c-myc, to the derivative chromosomes of a 3;8 translocation associated with familial renal cancer. Cytometry. 7:589-594.

28. Harper, M. E., and G. F. Saunders. 1981. Localization of single copy DNA sequences on G-banded human chromosomes by in situ hybridization. Chromosoma. 83:431-439.

29. Goode, M. E., P. vanTuinen, D. H. Ledbetter, and S. P. Daiger. 1986. The anonymous polymorphic DNA clone DIS1 previously mapped to human chromosome $1 \mathrm{p} 36$ by in situ hybridization, is from chromosome 3 and is duplicated on chromosome 1. Am. J. Hum. Genet. 38:437-446.

30. Carritt, B., H. M. Welch, and N. J. Parry-Jones. 1986. Sequences homologous to the human D1S1 locus present on human chromosome 3. Am. J. Hum. Genet. 38:428-436.

31. Donlon, T. A., and R. E. Magenis. 1984. Localization of the cloned segment of lambda Ch4A-H3 to chromosome 1 band p36:a comfirmation of locus D1S1. Cytogenet. Cell Genet. 37:454-455.

32. Naylor, S. L., A. Y. Sakaguchi, J. F. Gusella, D. Housman, and T. B. Shows. 1982. Mapping of an arbitrary restriction polymorphism (ARP2) to human chromosome 3. Cytogenet. Cell Genet. 32:302.

33. Yang, F., J. B. Lum, J. R. McGill, C. M. Moore, S. L. Naylor, P. H. van Bragt, W. D. Baldwin, and B. H. Bowman. 1984. Human transferrin: cDNA characterization and chromosomal localization. Proc. Natl. Acad. Sci. USA. 81:2752-2756.

34. Yang, F., S. L. Naylor, J. B. Lum, S. Cutshaw, J. L. McCombs, K. H. Naberhaus, J. R. McGill, G. S. Adrian, C. M. Moore, D. R. Barnett, and B. H. Bowman. 1986. Characterization, mapping, and expression of the human ceruloplasmin gene. Proc. Natl. Acad. Sci. USA. 83:3257-3261.

35. Naylor S. L., A. Y. Sakaguchi, L. P. Shen, G. I. Bell, W. J. Rutter, and T. B. Shows. 1983. Polymorphic human somatostatin gene is located on chromosome 3. Proc. Natl. Acad. Sci. USA. 80:26862689.

36. Cavenee, W., R. Leach, T. Mohandas, P. Pearson, and R. White. 1984. Isolation and regional localization of DNA segments revealing polymorphic loci from human chromosome 13. Am. J. Hum. Genet. 36:10-24.

37. Wurster-Hill, D. H., L. A. Cannizzaro, O. S. Pettengill, G. D. Sorenson, C. C. Cate, and L. H. Maurer. 1984. Cytogenetics of small cell carcinoma of the lung. Cancer Genet. and Cytogenet. 13:303-330.

38. Morstyn, G., D. C. Ihde, A. S. Lichter, P. A. Bunn, D. N. Carney, E. Glatstein, and J. D. Minna. 1984. Small cell lung cancer 1973-1983: early progress and recent obstacles. Int. J. Radiat. Oncol. Biol. Phys. 10:515-539.

39. Knudson, A. G. 1975. The genetics of childhood cancer. Cancer. 35:1022-1026.

40. Harris, H., O. J. Miller, G. Klein, P. Worst, and T. Tachibana 1969. Suppression of malignancy by cell fusion. Nature (Lond.). 223:363-368

41. Weissman, B. E., P. J. Saxon, S. R. Pasquale, G. R. Jones, A. G. Geiser, and E. J. Stanbridge. 1987. Introduction of a normal chromosome 11 into a Wilms' tumor cell line controls its tumorigenic expression. Science (Wash. DC). 236:175-180.

42. Zbar, B., H. Brauch, C. Talmadge, and M. Linehan. 1987. Loss of alleles of loci on the short arm of chromosome 3 in renal cell carcinoma. Nature (Lond.). 327:721-724.

43. Cohen, A. J., F. P. Li, S. Berg, D. J. Marchetto, S. Tsai, S. C. Jacobs, and R. S. Brown. 1979. Hereditary renal-cell carcinoma associated with a chromosomal translocation. N. Engl. J. Med. 301:592595.

44. Pathak, S., L. C. Strong, R. E. Ferrell, and A. Trindade. 1982. Familial renal cell carcinoma with a 3;11 chromosome translocation limited to tumor cells. Science (Wash. DC). 217:939-941. 